\title{
Mycotoxin content in grain of spring barley cultivated in the organic and conventional production systems in southeastern Poland
}

\author{
Zawartość mikotoksyn w ziarnie jęczmienia jarego uprawianego \\ w ekologicznym i konwencjonalnym systemie produkcji \\ na terenie południowo-wschodniej Polski
}

\author{
Agnieszka Pałka*, Ewa Solarska
}

\section{Summary}

The aim of the study was to compare the content of mycotoxins in grain of organic and conventional spring barley cultivated in 2006-2008. Enzyme-Linked ImmunoSorbent Assays ELISA were used to identify aflatoxins, ochratoxin A, T-2 toxin, deoxynivalenol and zearalenone. Deoxynivalenol was detected the most frequently in the barley samples. The highest level of mycotoxins occurred in the samples from 2008 and the lowest in 2007. In 2006 the samples from the organic system contained less total mycotoxins, and in 2008 only slighlty less in the samples from the conventional system. However, each year the grain from the organic system was less conatimaned by mycotoxins occurring in stored grains. The content of mycotoxins in 2007 in the samples from organic and conventional system remained at a similar level. The diverse mycotoxin content in the analyzed samples of barley may be related to the weather conditions in individual years and the farming system.

Key words: Fusarium; mycotoxins; barley; production system; ELISA

\section{Streszczenie}

Celem pracy było porównanie zawartości mikotoksyn w ziarnie jęczmienia jarego pochodzącego z upraw ekologicznych i konwencjonalnych w latach 2006-2008. Do identyfikacji aflatoksyn, ochratoksyny A, toksyny T-2, deoksyniwalenolu oraz zearalenonu użyto testów immunoenzymatycznych ELISA. Spośród badanych prób jęczmienia najwięcej zanieczyszczonych było deoksyniwalenolem. Najwyższy poziom mikotoksyn występował w próbkach z 2008 roku, a najniższy w 2007 roku. W 2006 roku mniej mikotoksyn ogółem zawierały próbki pochodzące z systemu ekologicznego, a w 2008 roku tylko minimalnie mniej z systemu konwencjonalnego, przy czym w każdym roku ziarno z ekologicznego systemu uprawy było słabiej zanieczyszczone przez mikotoksyny przechowalnicze. Zawartość mikotoksyn w 2007 roku w próbkach z systemu ekologicznego i konwencjonalnego utrzymywała się na podobnym poziomie. Zróżnicowana zawartość mikotoksyn w badanych próbkach jęczmienia była związana z warunkami pogodowymi w poszczególnych latach oraz z systemem uprawy.

Słowa kluczowe: Fusarium; mikotoksyny; jęczmień; system produkcji; ELISA

Uniwersytet Przyrodniczy w Lublinie

Katedra Biotechnologii, Mikrobiologii i Żywienia Człowieka

Skromna 8, 20-704 Lublin

*corresponding author: aga.f@op.pl 


\section{Wstęp / Introduction}

Toksyny fuzaryjne to produkty metabolizmu grzybów z rodzaju Fusarium. Gatunki o potencjalnie największej zdolności toksynotwórczej to Fusarium graminearum, Fusarium sporotrichioides, Fusarium verticillioides i Fusarium culmorum. Grzyby te porażają wiele gatunków roślin uprawnych, w tym głównie zboża, wywołując fuzariozy, takie jak zgorzel siewek, fuzaryjną zgorzel podstawy źdźbła i korzeni, fuzariozę kłosów i fuzariozę liści zbóż. Szczególnie groźna jest fuzarioza kłosa, a do wytwarzania toksyn w ziarnie dochodzić może już w czasie wegetacji zbóż. Rozwój choroby zależy od warunków pogody, a w największym stopniu od nadmiernej wilgotności powietrza. Istotne znaczenie ma także uprawiany gatunek zboża (Arseniuk i Góral 2005a; Fiedorow i wsp. 2008; Libudzisz i wsp. 2008). Trichoteceny są najczęściej występującymi mikotoksynami fuzaryjnymi w zbożach. Wśród trichotecenów wyróżnia się mikotoksyny typu A i B. Trichoteceny typu A, takie jak T-2, HT-2, diacetoxyscirpenol (DAS) są bardziej toksyczne niż trichoteceny typu B, do których należą deoksyniwalenol (DON) i nivalenol (NIV) (Maier i wsp. 2006; Solarska i wsp. 2008). Występowaniu grzybów fuzaryjnych i produkowaniu przez nie toksyn sprzyjają warunki klimatu umiarkowanego, czyli ciepła, wilgotna jesień i wczesna zima. Trichoteceny mają silnie toksyczne działanie (Arseniuk i Góral 2005b). Wśród trichotecenów, najbardziej toksyczna jest toksyna T-2, produkowana przede wszystkim przez $F$. sporotrichioides i Fusarium poae. Deoksyniwalenol jest wytwarzany głównie przez $F$. graminearum i $F$. culmorum. Jest to najczęściej występująca mikotoksyna w ziarnie zbóż, szkodliwa zarówno dla roślin, jak i dla zwierząt oraz ludzi (Arseniuk i Góral 2005b). Objawy skażenia deoksyniwalenolem to wymioty, biegunka, leukocytoza, podrażnienie i zapalenie skóry oraz tkanek podskórnych, krwotok w narządach wewnętrznych, a także zatrzymanie krążenia prowadzące do śmierci. Przewlekłe przyjmowanie niskich dawek prowadzi do obniżenia apetytu, anoreksji, redukcji masy ciała, zmian neuroendokrynologicznych oraz immunologicznych (Balas 2006).

Zearalenon jest mikotoksyną o właściwościach estrogennych wytwarzaną przez grzyby: F. graminearum, F. culmorum, Fusarium crookwellense, Fusarium roseum, Fusarium tricinctum i Fusarium moniliforme. Jego obecność można wykryć w kukurydzy i produktach z niej wytworzonych oraz w innych zbożach, takich jak jęczmień, pszenica i owies (Aljicevic i wsp. 2008). Zearalenon i jego pochodne nie wykazują szczególnie wysokiej toksyczności ostrej, mają wyraźnie działanie estrogenne i anaboliczne (Balas 2006).

Aflatoksyny produkowane są najczęściej przez Aspergillus flavus, Aspergillus parasiticus i Aspergillus nomius. Najbardziej znane to aflatoksyny $B_{1}, B_{2}, G_{1}, G_{2}, M_{1}$. Największą toksycznością charakteryzuje się aflatoksyna $\mathrm{B}_{1}$. Aflatoksyny mają działanie kancerogenne, teratogenne, mutagenne i immunosupresyjne. Mogą także powodować uszkodzenia nerek i centralnego układu nerwowego (Aljicevic i wsp. 2008). Ochratoksyna A (OTA) produkowana jest przez Aspergillus ochraceus, Aspergillus sclerotiorum, Aspergillus sulphureus, a także różne gatunki Penicillium spp. (P. verrucosum, $P$. purpugenum, $P$. commune). Wykazuje działanie nefrotoksyczne i nefrokancerogenne oraz immunosupresyjne. Najczęściej zanieczyszczenie zbóż aflatoksynami i ochratoksyną A pojawia się po zbiorach i wynika z nieprawidłowego ich przechowywania. Czasami dochodzi do zanieczyszczenia zboża przez te mikotoksyny już na polu podczas długiego okresu oczekiwania na zbiór w warunkach podwyższonej wilgotności (Balas 2006; Aljicevic i wsp. 2008).

Celem badań było określenie zawartości mikotoksyn w ziarnie jęczmienia jarego pochodzącego $\mathrm{z}$ upraw ekologicznych i konwencjonalnych przy użyciu metody ELISA.

\section{Materiały i metody / Materials and methods}

Materiał biologiczny do badań stanowiły ziarniaki jęczmienia jarego uprawianego w ekologicznym i konwencjonalnym systemie produkcji w latach 2006-2008 pochodzące od rolników indywidualnych z terenu województw lubelskiego i świętokrzyskiego. Dane dotyczące miejscowości, w których znajdowały się te gospodarstwa, daty pobierania próbek oraz przedplonu zostały zamieszczone w tabelach 1., 2. i 3. Zebrane próbki ziarna jęczmienia przechowywano w temperaturze $-20^{\circ} \mathrm{C}$ do czasu analizy. Badano 16 próbek ziarna jęczmienia z 2006 roku (8 z ekologicznego systemu uprawy i 8 z konwencjonalnego systemu uprawy), 12 próbek z 2007 roku (6 z ekologicznego systemu uprawy i 6 z konwencjonalnego systemu uprawy) i 14 próbek z 2008 roku (6 z ekologicznego systemu uprawy i 8 z konwencjonalnego systemu uprawy).

Badania przeprowadzono za pomocą immunoenzymatycznej metody ELISA. W analizach użyto ilościowe testy AgraQuant ${ }^{\circledR}$ firmy Romer Labs ${ }^{\circledR}$ na obecność: aflatoksyn, ochratoksyny A, deoksyniwalenolu, toksyny T-2 oraz zearalenonu.

Próbki przygotowano zgodnie z zaleceniem producenta zestawów do wykrywania mikotoksyn. Ziarniaki mielono w ultraodśrodkowym młynku laboratoryjnym Retzch ZM 200 i odważano po $20 \mathrm{~g}$ materiału. Próbki przeznaczone do wykrywania zawartości aflatoksyn, ochratoksyny A, toksyny T-2 oraz zearalenonu mieszano z 70\% metanolem, a przeznaczone do określania zawartości deoksyniwalenolu mieszano z wodą destylowaną. Następnie je wytrząsano i przesączano. Próbki do badań na obecność aflatoksyn i ochratoksyny A przygotowano przez przeniesienie po $1 \mathrm{ml}$ sporządzonego przesączu do probówek Eppendorfa. Przesącz przygotowany do wykrywania deoksyniwalenolu i toksyny T-2 w ilości odpowiednio 250 i $100 \mu$ uzupełniano 
do $1 \mathrm{ml}$ wodą destylowaną, a ten w którym badano zawartość zearalenolu mieszano z 70\% metanolem w proporcji $1: 4$ do uzyskania $1 \mathrm{ml}$ mieszaniny.

W testach dotyczących wykrywania wszystkich badanych mikotoksyn można wyróżnić te same główne etapy. Pierwszy z nich polegał na umieszczeniu w dołkach testowych po $200 \mu \mathrm{l}$ koniugatu. Następnie dodawano po $100 \mu \mathrm{l}$ standardów i badanych próbek. Po wymieszaniu zawartości dołków przenoszono po $100 \mu$ na płytkę opłaszczoną przeciwciałami i inkubowano $\mathrm{w}$ temperaturze pokojowej przez 10 minut w przypadku próbek do oznaczania ochratoksyny A, toksyny T-2 oraz zearalenonu oraz 15 minut w przypadku prób na obecność aflatoksyn i deoksyniwalenolu. Po przeprowadzeniu inkubacji zawartość dołków z opłaszczonej przeciwciałami płytki wylewano, a opróżnione dołki pięciokrotnie przemywano wodą dejonizowaną lub w przypadku prób na obecność deoksyniwalenolu specjalnym koncentratem (wash solution). Po zakończeniu przemywania dołki osuszano na papierze adsorpcyjnym. Do wysuszonych dołków dodawano po $100 \mu \mathrm{l}$ substratu. Podczas inkubacji w temperaturze pokojowej zachodziła reakcja barwna,w której intensywność barwy była odwrotnie proporcjonalna do stężenia wykrywanego antygenu. Po 5 minutach zatrzymano reakcję barwną przez dodanie do dołków po $100 \mu$ l stop solution.

Ilość barwnego produktu reakcji enzymatycznej określano metodą spektrofotometryczną, w czasie do 30 minut po dodaniu stop solution z wykorzystaniem czytnika Sunrise firmy Tecan przy długości fali $\lambda=450 \mathrm{~nm}$. Pomiar absorbancji analizowano za pomocą oprogramowania Magellan firmy Tecan. Koncentrację mikotoksyn obliczano z krzywej standardowej wyznaczanej na podstawie absorbancji standardów.

Zawartość mikotoksyn w ziarniakach jęczmienia analizowano statystycznie oprogramowaniem Statistica 13.1 używając testów U Manna-Whitneya i t-Studenta w zależności od rozkładu zmiennych oraz dwuczynnikowej analizy NPMANOVA (non-parametric MANOVA) wchodzącej w skład pakietu statystycznego Past 2.17c.

\section{Wyniki i dyskusja / Results and discussion}

Zaobserwowano różnice w zawartości badanych mikotoksyn w ziarnie jęczmienia jarego uprawianego w latach 2006-2008 w zależności od systemu uprawy oraz warunków pogodowych panujących w danym roku. Analiza statystyczna zawartości aflatoksyn, deoksyniwalenolu i ochratoksyny A w badanych ziarniakach jęczmienia z uprawy ekologicznej i konwencjonalnej w latach 2006-2008 nie wykazała istotnych statystycznie różnic w ilości tych mikotoksyn między systemami uprawy, z wyjątkiem zawartości aflatoksyn w 2006 roku, kiedy wykazano, że zawartość tej mikotoksyny w ziarnie jęczmienia z systemu ekologicznego była istotnie mniejsza w porównaniu z konwencjonalnym. Dwuczynnikowa analiza NPMANOVA nie wykazała różnic istotnych statystycznie w ilości tych mikotoksyn między systemem ekologicznym i konwencjonalnym w latach 2006-2008, natomiast wykazano istotne różnice w zawartości aflatoksyn i deoksyniwalenolu w zależności od roku pobrania prób ziarna jęczmienia, co może być związane $\mathrm{z}$ warunkami pogodowymi panującymi w danym roku (tab. 5).

Spośród badanych prób jęczmienia w ekologicznym i konwencjonalnym systemie uprawy w latach 2006-2008 najwięcej zanieczyszczonych było deoksyniwalenolem. W 2006 roku duże skażenie tą mikotoksyną obserwowano w systemie konwencjonalnym, w którym większość próbek zawierała DON w ilości powyżej $1 \mathrm{mg} / \mathrm{kg}$, a w systemie ekologicznym stwierdzono tylko jedną taką próbkę. Ustalony przez Komisję Europejską maksymalny limit zawartości DON w ziarnie zbóż wynoszący $1250 \mu \mathrm{g} / \mathrm{kg}$ nie został przekroczony w żadnej z próbek w 2006 roku (tab. 1) (Rozporządzenie 2006). W 2007 roku notowano słabsze zanieczyszczenie DON i na podobnym poziomie w obu systemach uprawy (tab. 2, rys. 2). Dopuszczalny limit DON w ziarnie zbóż wynoszący $1250 \mu \mathrm{g} / \mathrm{kg}$ został przekroczony w większości prób z systemu konwencjonalnego i połowie prób ziarna jęczmienia ekologicznego w 2008 roku (tab. 3).

Toksyna T-2 i zearalenon nie zostały wykryte w żadnej $\mathrm{z}$ testowanych prób zarówno $\mathrm{z}$ ekologicznego, jak i konwencjonalnego systemu uprawy w latach 2006-2008. Liczni autorzy wskazują na słabsze zanieczyszczenie przez mikotoksyny fuzaryjne zbóż uprawianych metodami ekologicznymi w porównaniu z konwencjonalnymi oraz na powszechne występowanie deoksyniwalenolu w ziarnie zbóż z obu systemów uprawy (Knudsen i wsp. 1995; Łukanowski i Sadowski 2005; Mazurkiewicz i wsp. 2008; Solarska i wsp. 2008; Bernhoft i wsp. 2012; Brodal i wsp. 2016; Remža i wsp. 2016). Mniejsza zawartość mikotoksyn w uprawach z ekologicznego systemu gospodarowania może być związana z występowaniem w nich większej różnorodności mikroorganizmów, a więc i większej konkurencji pomiędzy różnymi gatunkami grzybów oraz między grzybami i bakteriami, co powoduje, że rozwój gatunków grzybów chorobotwórczych nie osiągnie niebezpiecznego poziomu (Brandt i Leifert 2005). Ponadto wykazano, że stosowanie niektórych fungicydów w konwencjonalnym systemie uprawy hamuje rozwój grzybów, ale nie zmniejsza poziomu produkowanych przez nie mikotoksyn (Jennings i wsp. 2000; Edwards i wsp. 2001; Menniti i wsp. 2003). Edwards (2004) zaobserwował, że fungicydy mogą niekiedy stymulować powstawanie mikotoksyn, co może być odpowiedzią na stres u wielu gatunków grzybów. Odporność na środki grzybobójcze u grzybów może stymulować produkcję mikotoksyn lub zmiany w ich syntezie (D’Mello i wsp. 1998). Fungicydy mogą zmniejszać populację niektórych grzybów stymulując bezpośrednio albo w wyniku zmniejszonej konkurencji roz- 
Tabela 1. Zawartość mikotoksyn w ziarnie jęczmienia jarego uprawianego w ekologicznym i konwencjonalnym systemie produkcji w 2006 roku

Table 1. The mycotoxins content in grain of barley cultivated in the organic and conventional production systems in 2006

\begin{tabular}{|c|c|c|c|c|c|c|c|}
\hline $\begin{array}{l}\text { Próbki } \\
\text { Samples }\end{array}$ & $\begin{array}{l}\text { Województwo } \\
\text { Province }\end{array}$ & $\begin{array}{l}\text { Data zbioru } \\
\text { próbek } \\
\text { Harvest date } \\
\text { of samples }\end{array}$ & $\begin{array}{l}\text { System uprawy } \\
\text { Production } \\
\text { system }\end{array}$ & $\begin{array}{l}\text { Przedplon } \\
\text { Forecrop }\end{array}$ & $\begin{array}{c}\text { Aflatoksyny } \\
\text { Aflatoxins } \\
{[\mu \mathrm{g} / \mathrm{kg}]}\end{array}$ & $\begin{array}{c}\text { DON } \\
\text { Deoxynivalenol } \\
{[\mu \mathrm{g} / \mathrm{kg}]}\end{array}$ & $\begin{array}{c}\text { Ochratoksyna A } \\
\text { Ochratoxin A } \\
{[\mu \mathrm{g} / \mathrm{kg}]}\end{array}$ \\
\hline $\begin{array}{l}\text { Ae1 } \\
\text { Wierzchoniów }\end{array}$ & lubelskie & 16.08 & $\begin{array}{c}\text { ekologiczny } \\
\text { organic }\end{array}$ & $\begin{array}{c}\text { owies } \\
\text { oat }\end{array}$ & 0 & 740 & 0 \\
\hline $\begin{array}{l}\text { Ae4 } \\
\text { Annówka }\end{array}$ & lubelskie & 16.08 & $\begin{array}{c}\text { ekologiczny } \\
\text { organic }\end{array}$ & $\begin{array}{c}\text { łąka } \\
\text { meadow }\end{array}$ & 1,53 & 1140 & 3,68 \\
\hline $\begin{array}{l}\mathrm{Be} 2 \\
\text { Majdan } \\
\text { Starowiejski }\end{array}$ & lubelskie & 3.08 & $\begin{array}{c}\text { ekologiczny } \\
\text { organic }\end{array}$ & $\begin{array}{c}\text { mieszanka zbóż } \\
\text { cereal mix }\end{array}$ & 1,83 & 750 & 4,7 \\
\hline $\begin{array}{l}\text { Be4 } \\
\text { Kolonia } \\
\text { Olchowiec } \\
\end{array}$ & lubelskie & 3.08 & $\begin{array}{c}\text { ekologiczny } \\
\text { organic }\end{array}$ & $\begin{array}{l}\text { pszenica } \\
\text { wheat }\end{array}$ & 1,84 & 750 & 0 \\
\hline $\begin{array}{l}\mathrm{Xe} 2 \\
\text { Białopole } \\
\end{array}$ & lubelskie & 8.08 & $\begin{array}{c}\text { ekologiczny } \\
\text { organic }\end{array}$ & $\begin{array}{c}\text { buraki } \\
\text { fodder beet }\end{array}$ & 0 & 750 & 0 \\
\hline $\begin{array}{l}\text { Re1 } \\
\text { Małyszyn } \\
\text { Dolny } \\
\end{array}$ & świętokrzyskie & 29.08 & $\begin{array}{c}\text { ekologiczny } \\
\text { organic }\end{array}$ & $\begin{array}{l}\text { brak danych } \\
\text { no data }\end{array}$ & 1,84 & 740 & 0 \\
\hline $\begin{array}{l}\text { Re2 } \\
\text { Małyszyn } \\
\text { Dolny }\end{array}$ & świętokrzyskie & 29.08 & $\begin{array}{c}\text { ekologiczny } \\
\text { organic }\end{array}$ & $\begin{array}{c}\text { mieszanka zbóż } \\
\text { cereal mix }\end{array}$ & 0 & 740 & 0 \\
\hline $\begin{array}{l}\text { Re5 } \\
\text { Małyszyn } \\
\text { Górny } \\
\end{array}$ & świętokrzyskie & 29.08 & $\begin{array}{c}\text { ekologiczny } \\
\text { organic }\end{array}$ & $\begin{array}{c}\text { ziemniaki, } \\
\text { pszenica } \\
\text { potatoes, wheat }\end{array}$ & 0 & 740 & 0 \\
\hline Kiełczewice & lubelskie & 3.08 & $\begin{array}{c}\text { konwencjonalny } \\
\text { conventional }\end{array}$ & $\begin{array}{c}\text { pszenica } \\
\text { wheat }\end{array}$ & 1,9 & 1090 & 2,93 \\
\hline $\begin{array}{l}\text { MG } \\
\text { Zemborzyce }\end{array}$ & lubelskie & 14.08 & $\begin{array}{c}\text { konwencjonalny } \\
\text { conventional }\end{array}$ & $\begin{array}{c}\text { mieszanka zbóż } \\
\text { cereal mix }\end{array}$ & 1,95 & 1130 & 3,51 \\
\hline Zemborzyce & lubelskie & 14.08 & $\begin{array}{c}\text { konwencjonalny } \\
\text { conventional }\end{array}$ & $\begin{array}{c}\text { pszenica } \\
\text { wheat }\end{array}$ & 1,85 & 1120 & 3,64 \\
\hline $\begin{array}{l}\mathrm{K} \\
\text { Zemborzyce }\end{array}$ & lubelskie & 14.08 & $\begin{array}{c}\text { konwencjonalny } \\
\text { conventional }\end{array}$ & $\begin{array}{c}\text { mieszanka zbóż } \\
\text { cereal mix }\end{array}$ & 1,51 & 1140 & 0 \\
\hline $\begin{array}{l}\mathrm{M} \\
\text { Tomaszowice }\end{array}$ & lubelskie & 14.08 & $\begin{array}{c}\text { konwencjonalny } \\
\text { conventional }\end{array}$ & $\begin{array}{c}\text { brak danych } \\
\text { no data } \\
\end{array}$ & 1,9 & 1140 & 2,72 \\
\hline $\begin{array}{l}\text { H } 1 \\
\text { Miłocin }\end{array}$ & lubelskie & 14.08 & $\begin{array}{c}\text { konwencjonalny } \\
\text { conventional }\end{array}$ & $\begin{array}{c}\text { pszenica } \\
\text { wheat }\end{array}$ & 1,8 & 740 & 0 \\
\hline $\begin{array}{l}\text { H } 2 \\
\text { Miłocin }\end{array}$ & lubelskie & 14.08 & $\begin{array}{c}\text { konwencjonalny } \\
\text { conventional }\end{array}$ & $\begin{array}{c}\text { pszenica } \\
\text { wheat }\end{array}$ & 1,83 & 740 & 0 \\
\hline
\end{tabular}

wój innych grzybów i powodowanie przez nie infekcji na zbożach. Stosowanie fungicydów zmniejsza częstotliwość i poziom zanieczyszczenia mikotoksynami w niektórych uprawach w poszczególnych latach, ale rzadko fungicydy są w stanie całkowicie wyeliminować ryzyko infekcji powodowanych przez grzyby i tworzenia przez nie mikotoksyn (Benbrook 2006). Na występowanie grzybów z rodzaju Fusarium wpływają przede wszystkim warunki klimatyczne, szczególnie opady deszczu i temperatura w fazie kwitnienia zbóż oraz czynniki rolnicze, takie jak sposób uprawy gleby, nawożenie, płodozmian i stosowanie fungicydów (Bottalico i Perrone 2002; Solarska i wsp. 2008). Niepatogeniczne
Fusarium spp. i fluorescencyjne Pseudomonas spp. odgrywają kluczową rolę w hamowaniu rozwoju patogenicznych szczepów Fusarium spp., także tych, które produkują mikotoksyny (Mazzola 2002).

Rośliny pod wpływem stresu wywołanego wysoką temperaturą lub innymi czynnikami środowiskowymi są bardziej podatne na infekcje powodowane przez grzyby toksynotwórcze (Abbas i wsp. 2002). Gleby w gospodarstwach ekologicznych mają zazwyczaj wysoką zawartość materii organicznej, dlatego w okresie suszy utrzymują więcej wilgoci niż podobne gleby w systemie konwencjonalnym w wyniku czego, rośliny rosnące w gospodarstwach ekolo- 
Tabela 2. Zawartość mikotoksyn w ziarnie jęczmienia jarego uprawianego w ekologicznym i konwencjonalnym systemie produkcji w 2007 roku

Table 2. The mycotoxins content in grain of barley cultivated in the organic and conventional production systems in 2007

\begin{tabular}{|c|c|c|c|c|c|c|c|}
\hline $\begin{array}{l}\text { Próbki } \\
\text { Samples }\end{array}$ & $\begin{array}{l}\text { Województwo } \\
\text { Province }\end{array}$ & $\begin{array}{l}\text { Data zbioru } \\
\text { próbek } \\
\text { Harvest date } \\
\text { of samples }\end{array}$ & $\begin{array}{l}\text { System uprawy } \\
\text { Production } \\
\text { system }\end{array}$ & $\begin{array}{l}\text { Przedplon } \\
\text { Forecrop }\end{array}$ & $\begin{array}{c}\text { Aflatoksyny } \\
\text { Aflatoxins } \\
{[\mu \mathrm{g} / \mathrm{kg}]}\end{array}$ & $\begin{array}{c}\text { DON } \\
\text { Deoxynivalenol } \\
{[\mu \mathrm{g} / \mathrm{kg}]}\end{array}$ & $\begin{array}{c}\text { Ochratoksyna A } \\
\text { Ochratoxin A } \\
{[\mu \mathrm{g} / \mathrm{kg}]}\end{array}$ \\
\hline $\begin{array}{l}\text { Ae6 } \\
\text { Sułoszyn }\end{array}$ & lubelskie & 9.08 & $\begin{array}{c}\text { ekologiczny } \\
\text { organic }\end{array}$ & $\begin{array}{l}\text { brak danych } \\
\text { no data }\end{array}$ & 0 & 340 & 0 \\
\hline $\begin{array}{l}\text { Be3 } \\
\text { Tokarówka }\end{array}$ & lubelskie & 6.08 & $\begin{array}{c}\text { ekologiczny } \\
\text { organic }\end{array}$ & $\begin{array}{c}\text { tymianek, } \\
\text { pszenica } \\
\text { thyme, wheat }\end{array}$ & 0 & 270 & 0 \\
\hline $\begin{array}{l}\text { Be4 } \\
\text { Kolonia } \\
\text { Olchowiec }\end{array}$ & lubelskie & 6.08 & $\begin{array}{l}\text { ekologiczny } \\
\text { organic }\end{array}$ & $\begin{array}{l}\text { brak danych } \\
\text { no data }\end{array}$ & 0 & 0 & 0 \\
\hline $\begin{array}{l}\text { Ce5 } \\
\text { Brzostówka }\end{array}$ & lubelskie & 16.08 & $\begin{array}{c}\text { ekologiczny } \\
\text { organic }\end{array}$ & $\begin{array}{c}\text { pszenica } \\
\text { wheat }\end{array}$ & 0 & 820 & 0 \\
\hline $\begin{array}{l}\text { Re1 } \\
\text { Małyszyn } \\
\text { Dolny }\end{array}$ & świętokrzyskie & 10.08 & $\begin{array}{c}\text { ekologiczny } \\
\text { organic }\end{array}$ & $\begin{array}{c}\text { pszenżyto, } \\
\text { ziemniaki } \\
\text { triticale, potatoes }\end{array}$ & 0 & 970 & 0 \\
\hline $\begin{array}{l}\text { Re4 } \\
\text { Małyszyn } \\
\text { Górny } \\
\end{array}$ & świętokrzyskie & 10.08 & $\begin{array}{c}\text { ekologiczny } \\
\text { organic }\end{array}$ & $\begin{array}{l}\text { brak danych } \\
\text { no data }\end{array}$ & 0 & 700 & 0 \\
\hline $\begin{array}{l}\text { Ak1 } \\
\text { Wierzchoniów }\end{array}$ & lubelskie & 9.08 & $\begin{array}{c}\text { konwencjonalny } \\
\text { conventional }\end{array}$ & $\begin{array}{c}\text { gorczyca } \\
\text { mustard }\end{array}$ & 0 & 0 & 0 \\
\hline $\begin{array}{l}\text { Ak5 } \\
\text { Annówka }\end{array}$ & lubelskie & 9.08 & $\begin{array}{c}\text { konwencjonalny } \\
\text { conventional }\end{array}$ & $\begin{array}{c}\text { pszenżyto } \\
\text { triticale }\end{array}$ & 0 & 980 & 0 \\
\hline $\begin{array}{l}\text { Bk4 } \\
\text { Kolonia } \\
\text { Olchowiec }\end{array}$ & lubelskie & 6.08 & $\begin{array}{l}\text { konwencjonalny } \\
\text { conventional }\end{array}$ & $\begin{array}{c}\text { pszenica } \\
\text { wheat }\end{array}$ & 0 & 590 & 0 \\
\hline $\begin{array}{l}\text { Ck1 } \\
\text { Zezulin }\end{array}$ & lubelskie & 16.08 & $\begin{array}{c}\text { konwencjonalny } \\
\text { conventional }\end{array}$ & $\begin{array}{c}\text { brak danych } \\
\text { no data }\end{array}$ & 0 & 470 & 0 \\
\hline $\begin{array}{l}\text { Ck2 } \\
\text { Zezulin }\end{array}$ & lubelskie & 16.08 & $\begin{array}{c}\text { konwencjonalny } \\
\text { conventional }\end{array}$ & $\begin{array}{c}\text { pszenica } \\
\text { wheat }\end{array}$ & 1,17 & 560 & 0 \\
\hline $\begin{array}{l}\text { Ck3 } \\
\text { Brzostówka }\end{array}$ & lubelskie & 16.08 & $\begin{array}{c}\text { konwencjonalny } \\
\text { conventional }\end{array}$ & $\begin{array}{c}\text { pszenżyto, owies } \\
\text { triticale, oat }\end{array}$ & 0 & 490 & 3,37 \\
\hline
\end{tabular}

gicznych są narażone na mniejszą ilość stresów związanych z przegrzaniem, co również zmniejsza ryzyko występowania mikotoksyn (Benbrook 2006).

Wyższy poziom nawożenia w konwencjonalnych gospodarstwach powoduje szybszy wzrost roślin zbożowych, dlatego uprawia się tam przede wszystkim odmiany karłowe, u których zwiększa się prawdopodobieństwo zanieczyszczenia przez zarodniki grzybów toksynotwórczych występujących w glebie (Benbrook 2006). Wykazano też, że wyższy poziom nawożenia $\mathrm{w}$ gospodarstwach konwencjonalnych może stymulować wzrost grzybów, zwłaszcza gatunków z rodzaju Fusarium wytwarzających mikotoksyny (Gunst i wsp. 2005).

W 2006 roku występowanie aflatoksyn i ochratoksyny A zanotowano w próbach badanego ziarna z obu systemów uprawy. Skażenie aflatoksynami było większe w ziarnie z systemu konwencjonalnego, gdyż wszystkie próby były nimi zanieczyszczone na poziomie od $1,51 \mathrm{do} 1,95 \mu \mathrm{g} / \mathrm{kg}$. W ekologicznym jęczmieniu stwierdzono obecność tych mikotoksyn w połowie prób i ich zawartość wynosiła od 1,53 do $1,84 \mu \mathrm{g} / \mathrm{kg}$. Ochratoksynę A w 2006 roku zanotowano w 1/4 próbek z ekologicznego systemu uprawy i najwyższa jej zawartość wynosiła $4,7 \mu \mathrm{g} / \mathrm{kg}$. Natomiast w systemie konwencjonalnym połowa próbek w 2006 roku zanieczyszczona była tą mikotoksyną i jej najwyższa zawartość wynosiła 3,64 $\mu \mathrm{g} / \mathrm{kg}$ (tab. 1, rys. 1).

W 2007 roku obecność aflatoksyn i ochratoksyny A stwierdzono tylko w pojedynczych próbach z konwencjonalnego systemu produkcji i ich zawartość wynosiła odpowiednio $1,17 \mathrm{oraz} 3,37 \mu \mathrm{g} / \mathrm{kg}$ (tab. 2). Natomiast w 2008 roku zaobserwowano również większe skażenie aflatoksynami ziarna z uprawy konwencjonalnej, gdyż były one obecne w ponad połowie próbek $\mathrm{z}$ tego systemu i najwyższa ich zawartość wynosiła $1,93 \mu \mathrm{g} / \mathrm{kg}$, a w przypadku 
Tabela 3. Zawartość mikotoksyn w ziarnie jęczmienia jarego uprawianego w ekologicznym i konwencjonalnym systemie produkcji w 2008 roku

Table 3. The mycotoxins content in grain of barley cultivated in the organic and conventional production systems in 2008

\begin{tabular}{|c|c|c|c|c|c|c|c|}
\hline $\begin{array}{l}\text { Próbki } \\
\text { Samples }\end{array}$ & $\begin{array}{l}\text { Województwo } \\
\text { Province }\end{array}$ & $\begin{array}{l}\text { Data zbioru } \\
\text { próbek } \\
\text { Harvest date } \\
\text { of samples }\end{array}$ & $\begin{array}{l}\text { System uprawy } \\
\text { Production } \\
\text { system }\end{array}$ & $\begin{array}{l}\text { Przedplon } \\
\text { Forecrop }\end{array}$ & $\begin{array}{c}\text { Aflatoksyny } \\
\text { Aflatoxins } \\
{[\mu \mathrm{g} / \mathrm{kg}]}\end{array}$ & $\begin{array}{c}\text { DON } \\
\text { Deoxynivalenol } \\
{[\mu \mathrm{g} / \mathrm{kg}]}\end{array}$ & $\begin{array}{c}\text { Ochratoksyna A } \\
\text { Ochratoxin A } \\
{[\mu \mathrm{g} / \mathrm{kg}]}\end{array}$ \\
\hline $\begin{array}{l}\text { Ae6 } \\
\text { Sułoszyn }\end{array}$ & lubelskie & 20.08 & $\begin{array}{c}\text { ekologiczny } \\
\text { organic }\end{array}$ & $\begin{array}{l}\text { por } \\
\text { leek }\end{array}$ & 0 & 1340 & 0 \\
\hline $\begin{array}{l}\mathrm{Be} 2 \\
\text { Majdan } \\
\text { Starowiejski }\end{array}$ & lubelskie & 21.08 & $\begin{array}{c}\text { ekologiczny } \\
\text { organic }\end{array}$ & $\begin{array}{l}\text { pszenica } \\
\text { wheat }\end{array}$ & 0 & 1350 & 0 \\
\hline $\begin{array}{l}\text { Be4 } \\
\text { Kolonia } \\
\text { Olchowiec }\end{array}$ & lubelskie & 21.08 & $\begin{array}{c}\text { ekologiczny } \\
\text { organic }\end{array}$ & $\begin{array}{c}\text { pszenica } \\
\text { wheat }\end{array}$ & 1,27 & 1340 & 0 \\
\hline $\begin{array}{l}\text { Sk } \\
\text { Tokarówka }\end{array}$ & lubelskie & 21.08 & $\begin{array}{c}\text { ekologiczny } \\
\text { organic }\end{array}$ & $\begin{array}{c}\text { pszenica } \\
\text { wheat }\end{array}$ & 1,9 & 1230 & 0 \\
\hline $\begin{array}{l}\mathrm{Ba} \\
\text { Małyszyn Górny }\end{array}$ & świętokrzyskie & 28.08 & $\begin{array}{c}\text { ekologiczny } \\
\text { organic }\end{array}$ & $\begin{array}{c}\text { gryka } \\
\text { buckwheat }\end{array}$ & 1,43 & 1210 & 0 \\
\hline $\begin{array}{l}\text { Re4 } \\
\text { Małyszyn Górny }\end{array}$ & świętokrzyskie & 28.08 & $\begin{array}{c}\text { ekologiczny } \\
\text { organic }\end{array}$ & $\begin{array}{c}\text { pszenica } \\
\text { wheat }\end{array}$ & 0 & 1230 & 0 \\
\hline $\begin{array}{l}\text { Ak1 } \\
\text { Wierzchoniów }\end{array}$ & lubelskie & 20.08 & $\begin{array}{c}\text { konwencjonalny } \\
\text { conventional }\end{array}$ & $\begin{array}{l}\text { pszenżyto } \\
\text { triticale }\end{array}$ & 1,84 & 1320 & 0 \\
\hline $\begin{array}{l}\text { Ko } \\
\text { Majdan } \\
\text { Starowiejski }\end{array}$ & lubelskie & 21.08 & $\begin{array}{c}\text { konwencjonalny } \\
\text { conventional }\end{array}$ & $\begin{array}{c}\text { pszenica } \\
\text { wheat }\end{array}$ & 1,91 & 1110 & 2,22 \\
\hline $\begin{array}{l}\text { Bk4 } \\
\text { Kolonia } \\
\text { Olchowiec }\end{array}$ & lubelskie & 21.08 & $\begin{array}{c}\text { konwencjonalny } \\
\text { conventional }\end{array}$ & $\begin{array}{c}\text { brak danych } \\
\text { no data }\end{array}$ & 0 & 1290 & 0 \\
\hline $\begin{array}{l}\mathrm{Br} \\
\text { Majdan } \\
\text { Starowiejski } \\
\end{array}$ & lubelskie & 21.08 & $\begin{array}{c}\text { konwencjonalny } \\
\text { conventional }\end{array}$ & $\begin{array}{c}\text { pszenica } \\
\text { wheat }\end{array}$ & 0 & 1350 & 0 \\
\hline $\begin{array}{l}\text { Ko } \\
\text { Krynica }\end{array}$ & lubelskie & 2.09 & $\begin{array}{c}\text { konwencjonalny } \\
\text { conventional }\end{array}$ & $\begin{array}{l}\text { pszenżyto } \\
\text { triticale }\end{array}$ & 0 & 1360 & 0 \\
\hline $\begin{array}{l}\text { So } \\
\text { Kiełczewice }\end{array}$ & lubelskie & 21.08 & $\begin{array}{c}\text { konwencjonalny } \\
\text { conventional }\end{array}$ & $\begin{array}{c}\text { owies } \\
\text { oat }\end{array}$ & 1,93 & 1270 & 0 \\
\hline $\begin{array}{l}\mathrm{Bu} \\
\text { Brzostówka }\end{array}$ & lubelskie & 22.08 & $\begin{array}{c}\text { konwencjonalny } \\
\text { conventional }\end{array}$ & $\begin{array}{c}\text { gryka } \\
\text { buckwheat }\end{array}$ & 1,85 & 1250 & 0 \\
\hline $\begin{array}{l}\text { Ck1 } \\
\text { Zezulin }\end{array}$ & lubelskie & 22.08 & $\begin{array}{c}\text { konwencjonalny } \\
\text { conventional }\end{array}$ & $\begin{array}{l}\text { pszenica } \\
\text { wheat }\end{array}$ & 1,9 & 1210 & 0 \\
\hline
\end{tabular}

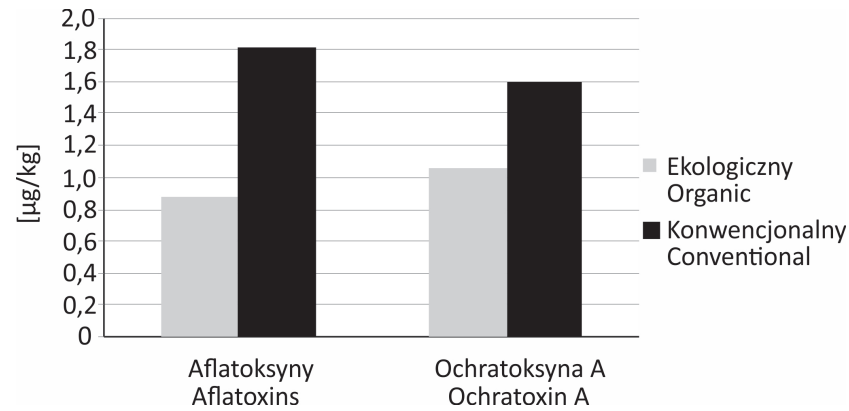

Rys. 1. Średnia zawartość aflatoksyn i ochratoksyny A w ziarnie jęczmienia jarego uprawianego w ekologicznym i konwencjonalnym systemie produkcji w 2006 roku

Fig. 1. The average content of aflatoxins and ochratoxin A in grain of barley cultivated in the organic and conventional production systems in 2006

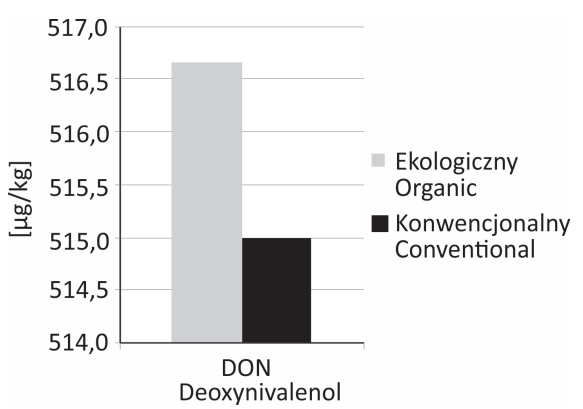

Rys. 2. Średnia zawartość deoksyniwalenolu w ziarnie jęczmienia jarego uprawianego w ekologicznym i konwencjonalnym systemie produkcji w 2007 roku

Fig. 2. The average content of deoksynivalenol in grain of barley cultivated in the organic and conventional production systems in 2007 
Tabela 4. Średnia zawartość badanych mikotoksyn w ziarnie jęczmienia jarego uprawianego w ekologicznym i konwencjonalnym systemie produkcji w latach 2006-2008 todchylenie standardowe

Table 4. The average content of mycotoxins analyzed in grain of barley cultivated in the organic and conventional production systems in 2006-2008 \pm standard deviation

\begin{tabular}{|c|c|c|c|c|c|c|c|}
\hline $\begin{array}{l}\text { Rok } \\
\text { Year }\end{array}$ & $\begin{array}{l}\text { System uprawy } \\
\text { Cultivation } \\
\text { system }\end{array}$ & $\begin{array}{c}\text { Średnia zawartość } \\
\text { badanych mikotoksyn } \\
\text { The average content } \\
\text { of mycotoxins } \\
\text { analyzed } \\
{[\mu \mathrm{g} / \mathrm{kg}]} \\
\pm \mathrm{SD}\end{array}$ & $\begin{array}{l}\text { Aflatoksyny } \\
\text { Aflatoxins } \\
{[\mu \mathrm{g} / \mathrm{kg}]} \\
\pm \mathrm{SD}\end{array}$ & $\begin{array}{c}\text { DON } \\
\text { Deoxynivalenol } \\
{[\mu \mathrm{g} / \mathrm{kg}]} \\
\pm \mathrm{SD}\end{array}$ & $\begin{array}{c}\text { Ochratoksyna A } \\
\text { Ochratoxin A } \\
{[\mu \mathrm{g} / \mathrm{kg}]} \\
\pm \mathrm{SD}\end{array}$ & $\begin{array}{c}\mathrm{T}-2 \\
{[\mu \mathrm{g} / \mathrm{kg}]} \\
\pm \mathrm{SD}\end{array}$ & $\begin{array}{l}\text { Zearalenon } \\
\text { Zearalenone } \\
{[\mu \mathrm{g} / \mathrm{kg}]} \\
\pm \mathrm{SD}\end{array}$ \\
\hline \multirow{2}{*}{2006} & $\begin{array}{l}\text { ekologiczny } \\
\text { organic }\end{array}$ & $159,135 \pm 326,7785$ & $0,880 \pm 0,9461$ & $793,75 \pm 139,9936$ & $1,047 \pm 1,9586$ & 0 & 0 \\
\hline & $\begin{array}{c}\text { konwencjonalny } \\
\text { conventional }\end{array}$ & $206,184 \pm 422,6837$ & $1,819 \pm 0,1348$ & $1027,5 \pm 178,1452$ & $1,6 \pm 1,7350$ & 0 & 0 \\
\hline \multirow{2}{*}{2007} & $\begin{array}{l}\text { ekologiczny } \\
\text { organic }\end{array}$ & $103,333 \pm 260,7328$ & 0 & $516,667 \pm 371,5194$ & 0 & 0 & 0 \\
\hline & $\begin{array}{l}\text { konwencjonalny } \\
\text { conventional }\end{array}$ & $103,151 \pm 246,626$ & $0,195 \pm 0,4776$ & $515 \pm 313,608$ & $0,562 \pm 1,3757$ & 0 & 0 \\
\hline \multirow{2}{*}{2008} & $\begin{array}{c}\text { ekologiczny } \\
\text { organic }\end{array}$ & $275,164 \pm 536,9177$ & $0,767 \pm 0,8650$ & $1283,333 \pm 66,2319$ & 0 & 0 & 0 \\
\hline & $\begin{array}{l}\text { konwencjonalny } \\
\text { conventional }\end{array}$ & $260,811 \pm 520,5599$ & $1,179 \pm 0,9765$ & $1270 \pm 81,9407$ & $0,277 \pm 0,7848$ & 0 & 0 \\
\hline
\end{tabular}

Tabela 5. Analiza statystyczna zawartości badanych mikotoksyn w ziarnie jęczmienia jarego uprawianego w ekologicznym i konwencjonalnym systemie produkcji w latach 2006-2008

Table 5. Statistical analysis of mycotoxins content in grain of barley cultivated in the organic and conventional production systems in 2006-2008

\begin{tabular}{|c|c|c|c|}
\hline $\begin{array}{l}\text { Rok } \\
\text { Year }\end{array}$ & $\begin{array}{l}\text { Aflatoksyny } \\
\text { Aflatoxins }\end{array}$ & $\begin{array}{c}\text { DON } \\
\text { Deoxynivalenol }\end{array}$ & $\begin{array}{c}\text { Ochratoksyna A } \\
\text { Ochratoxin A }\end{array}$ \\
\hline 2006 & $\begin{array}{c}\mathrm{p}=0,037 \\
\text { (test U Manna-Whitneya) } \\
\mathrm{p}<0,05\end{array}$ & $\begin{array}{c}p=0,130 \\
\text { (test U Manna-Whitneya) } \\
p>0,05\end{array}$ & $\begin{array}{c}\mathrm{p}=0,720 \\
\text { (test U Manna-Whitneya) } \\
\mathrm{p}>0,05\end{array}$ \\
\hline 2007 & $\begin{array}{c}p=0,699 \\
\text { (test U Manna-Whitneya) } \\
p>0,05\end{array}$ & $\begin{array}{c}\mathrm{p}=0,993 \\
\text { (test t-Studenta) } \\
\mathrm{p}>0,05\end{array}$ & $\begin{array}{c}\mathrm{p}=0,699 \\
\text { (test U Manna-Whitneya) } \\
\mathrm{p}>0,05\end{array}$ \\
\hline 2008 & $\begin{array}{c}\mathrm{p}=0,344 \\
\text { (test U Manna-Whitneya) } \\
\mathrm{p}>0,05\end{array}$ & $\begin{array}{c}p=0,710 \\
\text { (test t-Studenta) } \\
p>0,05\end{array}$ & $\begin{array}{c}p=0,754 \\
\text { (test U Manna-Whitneya) } \\
p>0,05\end{array}$ \\
\hline 2006-2008 & $\begin{array}{c}\mathrm{p}=0,0699 \mathrm{p}>0,05 \\
(\text { system uprawy) } \\
\mathrm{p}=0,0005 \mathrm{p}<0,05 \text { (rok) } \\
\text { (NPMANOVA) }\end{array}$ & $\begin{array}{c}\mathrm{p}=0,64 \mathrm{p}>0,05 \\
(\text { system uprawy) } \\
\mathrm{p}=0,0001 \mathrm{p}<0,05 \text { (rok) } \\
\text { (NPMANOVA) }\end{array}$ & $\begin{array}{c}\mathrm{p}=0,0784 \mathrm{p}>0,05 \\
(\text { system uprawy) } \\
\mathrm{p}=0,0506 \mathrm{p}>0,05 \\
(\text { rok) } \\
(\text { NPMANOVA) }\end{array}$ \\
\hline
\end{tabular}

system uprawy - cultivation system

jęczmienia ekologicznego połowa próbek zanieczyszczona była tą mikotoksyną i jej najwyższa zawartość wynosiła $1,9 \mu \mathrm{g} / \mathrm{kg}$. W 2008 roku obecność ochratoksyny A stwierdzono w jednej próbie z konwencjonalnej uprawy i jej zawartość wynosiła 2,22 $\mu \mathrm{g} / \mathrm{kg}$ (tab. 3, rys. 3). Ustalony przez Komisję Europejską maksymalny limit zawartości aflatoksyn i ochratoksyny A w ziarnie zbóż wynosi odpowiednio 4 i $5 \mu \mathrm{g} / \mathrm{kg}$ (Rozporządzenie 2006). W żadnej z badanych próbek jęczmienia zawartość tych mikotoksyn nie przekraczała poda- nych norm. Solarska i wsp. (2009) nie stwierdzili obecności ochratoksyny A i aflatoksyn w ziarnie pszenżyta z ekologicznego i konwencjonalnego systemu uprawy, co miało związek z dobrymi praktykami dotyczącymi zbioru i przechowywania suszonego ziarna. Elmholt i Rasmussen (2005) wykazali, że nie ma zależności między skażeniem przez Penicillium verrucosum zbóż uprawianych w systemie ekologicznym i zawartością ochratoksyny A w ziarnie. W ponad $80 \%$ badanych próbek jęczmienia, owsa, pszenicy, 
Tabela 6. Charakterystyka warunków pogody w latach 2006-2008 w Lublinie Table 6. Characterization of weather conditions in 2006-2008 in Lublin

\begin{tabular}{|c|c|c|c|c|c|c|c|c|}
\hline \multirow[t]{2}{*}{$\begin{array}{l}\text { Miesiąc } \\
\text { Month }\end{array}$} & \multicolumn{3}{|c|}{$\begin{array}{c}\text { Średnia miesięczna } \\
\text { temperatura w latach } \\
\text { Average month } \\
\text { temperature in years } \\
{\left[{ }^{\circ} \mathrm{C}\right]}\end{array}$} & \multirow{2}{*}{\begin{tabular}{|c|} 
Średnia miesięczna \\
temperatura $\mathrm{z}$ wielolecia \\
$1981-2010$ \\
Average month \\
temperature for the period \\
$1981-2010$ \\
{$\left[{ }^{\circ} \mathrm{C}\right]$}
\end{tabular}} & \multicolumn{3}{|c|}{$\begin{array}{c}\text { Suma opadów w latach } \\
\text { Sum of precipitation in years } \\
{[\mathrm{mm}]}\end{array}$} & \multirow{2}{*}{$\begin{array}{c}\text { Średnia miesięczna suma opadów } \\
\text { Z wielolecia 1981-2010 } \\
\text { Average monthly sum } \\
\text { of precipitation for the period } \\
1981-2010 \\
{[\mathrm{~mm}]}\end{array}$} \\
\hline & 2006 & 2007 & 2008 & & 2006 & 2007 & 2008 & \\
\hline Kwiecień - April & 9,4 & 8,4 & 9,1 & 8,0 & 16,7 & 17,5 & 39,6 & 39,8 \\
\hline Maj - May & 13,5 & 15,2 & 12,6 & 13,5 & 83,1 & 49,9 & 81,1 & 59,9 \\
\hline Czerwiec - June & 16,6 & 18,1 & 17,0 & 16,1 & 18,2 & 77,1 & 34,9 & 66,5 \\
\hline Lipiec - July & 21,2 & 18,9 & 18,3 & 18,2 & 6,3 & 111,3 & 80,2 & 80,6 \\
\hline Sierpień - August & 18,0 & 18,8 & 19,1 & 17,6 & 169,2 & 32,3 & 49,6 & 58,9 \\
\hline
\end{tabular}

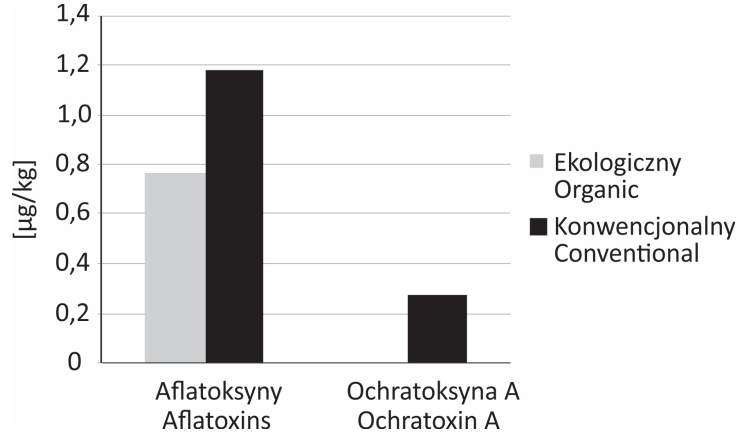

Rys. 3. Średnia zawartość aflatoksyn i ochratoksyny A w ziarnie jęczmienia jarego uprawianego w ekologicznym i konwencjonalnym systemie produkcji w 2008 roku

Fig. 3. The average content of aflatoxins and ochratoxin A in grain of barley cultivated in the organic and conventional production systems in 2008

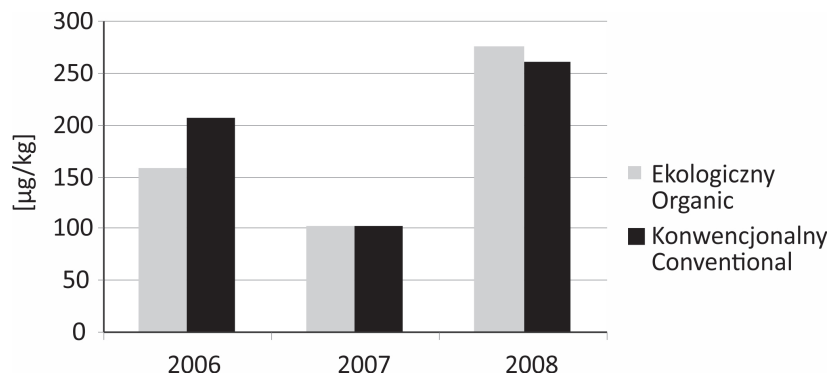

Rys. 4. Średnia zawartość badanych mikotoksyn w ziarnie jęczmienia jarego uprawianego w ekologicznym i konwencjonalnym systemie produkcji w latach 2006-2008

Fig. 4. The average content of mycotoxins analyzed in grain of barley cultivated in the organic and conventional production systems in 2006-2008

orkiszu i żyta z upraw ekologicznych stwierdzono występowanie $P$. verrucosum, co wskazuje na możliwość zanieczyszczenia ziarna przez OTA przed poddawaniem go suszeniu i przechowywaniu. Występowanie OTA może być związane z późnym terminem zbioru i wysoką wilgotnością ziarna. W ziarnie zbóż o wilgotności poniżej 17\% zawartość OTA utrzymuje się na niskim poziomie nieprzekraczającym dopuszczalnych norm $(5 \mu \mathrm{g} / \mathrm{kg})$. Limit zawartości OTA został przekroczony w ziarnie owsa i orkiszu o wilgotności powyżej $18 \%$, co może być związane z niedosuszeniem ziarna (Elmholt i Rasmussen 2005).

Zróżnicowana zawartość mikotoksyn w badanych próbkach jęczmienia z ekologicznego i konwencjonalnego systemu produkcji w latach 2006-2008 miała związek m.in. $\mathrm{z}$ warunkami pogodowymi w poszczególnych latach (tab. 6). Najwyższy poziom mikotoksyn występował w próbkach z 2008 roku, a najniższy w 2007 roku, kiedy obserwowano znaczące różnice w sumie opadów i średniej temperaturze w kwietniu, maju i czerwcu (tab. 4, 6, rys. 4). $\mathrm{W}$ poszczególnych latach wystąpiły także różnice w zawartości mikotoksyn w ziarnie jęczmienia pomiędzy systemami uprawy. W 2006 roku mniej mikotoksyn zawierały próbki pochodzące z systemu ekologicznego, a w 2008 roku minimalnie mniej pochodzące $\mathrm{z}$ systemu konwencjonalnego. Zawartość mikotoksyn w 2007 roku w próbkach z systemu ekologicznego i konwencjonalnego utrzymywała się na podobnym poziomie, przy czym w przypadku mikotoksyn przechowalniczych $\mathrm{w}$ tym roku badań nie zanotowano zanieczyszczenia nimi ziarna $\mathrm{w}$ systemie ekologicznym, a w pozostałych latach było ono mniejsze w tym systemie w porównaniu z konwencjonalnym (tab. 1, 2, 3).

\section{Wnioski / Conclusions}

1. Deoksyniwalenol był najczęściej występującą mikotoksyną w badanych próbach jęczmienia w ekologicznym $\mathrm{i}$ konwencjonalnym systemie produkcji w latach 2006-2008, natomiast toksyna T-2 i zearalenon nie zostały wykryte w żadnej z testowanych prób.

2. Ustalony przez Komisję Europejską maksymalny limit DON w ziarnie zbóż wynoszący $1250 \mu \mathrm{g} / \mathrm{kg}$ został prze- 
kroczony w próbkach z 2008 roku głównie jęczmienia uprawianego w systemie konwencjonalnym, ale również i w ekologicznym systemie uprawy, a limit zawartości aflatoksyn i ochratoksyny A wynoszący odpowiednio 4 i $5 \mu \mathrm{g} / \mathrm{kg}$ nie został przekroczony w żadnej z badanych próbek jęczmienia.
3. Zróżnicowana zawartość mikotoksyn w badanych próbkach jęczmienia z ekologicznego i konwencjonalnego systemu produkcji w latach 2006-2008 może być związana między innymi z warunkami pogodowymi w poszczególnych latach oraz systemem uprawy.

\section{Literatura / References}

Abbas H.K., Shier W.T., Gronwald J.W., Lee Y.W. 2002. Comparison of phytotoxicity and mammalian cytotoxicity of nontrichothecene mycotoxins. Journal of Natural Toxins 11 (3): 173-186.

Aljicevic M., Beslagic E., Zvizdic S., Hamzic S., Rebic V. 2008. Mycotoxins. HealthMED 2 (3): 176-182.

Arseniuk E., Góral T. 2005a. Mikotoksyny fuzaryjne w ziarnie zbóż i kukurydzy. [Fusarium mycotoxins in cereal and maize grain]. Hodowla Roślin i Nasiennictwo 3: 27-33.

Arseniuk E., Góral T. 2005b. Fuzarioza kłosów - czynniki sprawcze i gospodarcze znaczenie choroby. Instytut Hodowli i Aklimatyzacji Roślin w Radzikowie. www.pin.org.pl/hrin/txt/2005/3-6.rtf [dostęp: 14.03.2017].

Balas J. 2006. Mikotoksyny jako źródło zanieczyszczeń żywności pochodzenia roślinnego. [The mycotoxins as a source of contaminaton of food and fodder of plant origin]. Postępy Fitoterapii 2: 98-104.

Benbrook C.M. 2006. Breaking the mold - impacts of organic and conventional farming systems on mycotoxins in food and livestock feed. The Organic Center. Mycotoxin Report. www.organic-center.org/reportfiles/MycotoxinReport.pdf [Accessed: 20.04.2017].

Bernhoft A., Torp M., Clasen P.E., Løes A.K., Kristoffersen A.B. 2012. Influence of agronomic and climatic factors on Fusarium infestation and mycotoxin contamination of cereals in Norway. Food Additives and Contaminants Part A: Chemistry, Analysis, Control, Exposure and Risk Assessment 29 (7): 1129-1140. DOI: 10.1080/19440049.2012.672476.

Bottalico A., Perrone G. 2002. Toxigenic Fusarium species and mycotoxins associated with head blight in small-grain cereals in Europe. European Journal of Plant Pathology 108 (7): 611-624. DOI: 10.1023/A:1020635214971.

Brandt K., Leifert C. 2005. Healthier organic crop porducts - improving the nutritional quality and avoiding mycotoxin contamination. www.qlif.org/qlifnews/apri105/con2.html [Accessed: 20.04.2017].

Brodal G., Hofgaard I.S., Eriksen G.S., Bernhoft A., Sundheim L. 2016. Mycotoxins in organically versus conventionally produced cereal grains and some other crops in temperate regions. World Mycotoxin Journal 9 (5): 755-770. DOI: 10.3920/WMJ2016.2040.

D’Mello J.P., MacDonald A.M.C., Postel D., Dijksma W.T.P., Dujardin A., Placinta C.M. 1998. Pesticide use and mycotoxin production in Fusarium and Aspergillus phytopathogens. European Journal of Plant Pathology 104 (8): 741-751. DOI: 10.1023/ A:1008621505708.

Edwards S.G. 2004. Influence of agricultural practices on fusarium infection of cereals and subsequent contamination of grain by trichothecene mycotoxins. Toxicology Letters 153 (1): 29-35. DOI: 10.1016/j.toxlet.2004.04.022.

Edwards S.G., Pirgozliev S.R., Hare M.C., Jenkinson P. 2001. Quantification of trichothecene producing Fusarium species in harvested grain by competitive PCR to determine efficacies of fungicides against fusarium head blight of winter wheat. Applied and Environmental Microbiology 67 (4): 1575-1580. DOI: 10.1128/AEM.67.4.1575-1580.2001.

Elmholt S., Rasmussen P.H. 2005. Penicillium verrucosum occurrence and ochratoxin A contents in organically cultivated grain with special reference to ancient wheat types and drying practice. Mycopathologia 159 (3): 421-432. DOI: 10.1007/s11046-005-1152-5.

Fiedorow Z., Gołębniak B., Weber Z. 2008. Choroby roślin rolniczych. Wydawnictwo Akademii Rolniczej im. Augusta Cieszkowskiego, Poznań, 208 ss.

Gunst L., Krebs H., Dubois D., Forrer H.R. 2005. The effect of farming system, previous crop and fertilization on the incidence of ear diseases of wheat in the DOK trial. Research Conference on Organic Agriculture in the German-speaking Region. p. 117-120. Kassel University Press, March 1-4, 2005, Kassel, Germany.

Jennings P., Turner J.A., Nicholson P. 2000. Overview of Fusarium ear blight in the UK - effect of fungicide treatment on disease control and mycotoxin production. p. 707-712. The Brighton Crop Protection Conference: Pests and diseases. Proceedings of an International Conference: Held at the Brighton Hilton Metropole Hotel, UK, November 13-16, 2000, Tom 1, 1296 pp.

Knudsen M.B., Elmholt S., Hockenhull J., Jensen D.F. 1995. Distribution of saprophytic fungi antagonistic to Fusarium culmorum in two differently cultivated field soils, with special emphasis on the genus Fusarium. Biological Agriculture and Horticulture 12 (1): 61-79. DOI: $10.1080 / 01448765.1995 .9754723$.

Libudzisz Z., Kowal K., Żakowska Z. 2008. Mikrobiologia techniczna. Mikroorganizmy w biotechnologii, ochronie środowiska i produkcji żywności. Tom 2. Wydawnictwo Naukowe PWN, Warszawa, 564 ss.

Łukanowski A., Sadowski Cz. 2005. Wykorzystywanie metody PCR do badania jakości ziarna pszenicy ozimej uprawianej w systemach ekologicznym, integrowanym, konwencjonalnym oraz monokulturze w aspekcie fitopatologicznym. [The use of PCR assay for quality testing of grain of winter wheat cultivated in organic, integrated, conventional system and monoculture in phytopathological aspekt]. Acta Agrobotanica 58 (2): 55-69.

Maier F.J., Miedaner T., Hadeler B., Felk A., Salomon S., Lemmens M., Kassner H., Schäfer W. 2006. Involvement of trichothecenes in fusarioses of wheat, barley and maize evaluated by gene disruption of the richodiene synthase (Tri5) gene in three field isolates of different chemotype and virulence. Molecular Plant Pathology 7 (6): 449-461. DOI: 10.1111/j.1364-3703.2006.00351.x. 
Mazurkiewicz J., Solarska E., Kuzdraliński A., Muszyńska M. 2008. Wpływ sposobu nawożenia na występowanie toksyn fuzaryjnych w pszenicy ozimej. [The occurrence of Fusarium toxins in winter wheat depending on fertilization]. Journal of Research and Applications in Agricultural Engineering 53 (4): 15-17.

Mazzola M. 2002. Mechanisms of natural soil suppressiveness to soilborne diseases. Antonie Van Leeuwenhoek 81 (1-4): $557-564$.

Menniti A.M., Pancaldi D., Maccaferri M., Casalini L. 2003. Effect of fungicides on Fusarium head blight and deoxynivalenol content in durum wheat grain. European Journal of Plant Pathology 109 (2): 109-115. DOI: 10.1023/A:1022557819214.

Remža J., Lacko-Bartošová M., Kosík T. 2016. Fusarium mycotoxin content of Slovakian organic and conventional cereals. Journal of Central European Agriculture 17 (1): 164-175. DOI: 10.5513/JCEA01/17.1.1686.

Rozporządzenie Komisji (WE) NR 1881/2006 z dnia 19 grudnia 2006 r. ustalające najwyższe dopuszczalne poziomy niektórych zanieczyszczeń w środkach spożywczych. Dz. Urz. UE L 364/5 z dnia 20.12.2006 r.

Solarska E., Kuzdraliński A., Szymona J. 2009. The mycotoxin contamination of triticale cultivars cultivated in organic and conventional systems of production. Phytopathologia 53: 57-62.

Solarska E., Mazurkiewicz J., Fajbuś A., Muszyńska M. 2008. Wpływ przedplonu na występowanie trichotecenów fuzaryjnych w jęczmieniu jarym uprawianym w ekologicznym systemie produkcji. [The effect of forecrop on occurrence of fusarium trichothecens in spring barley cultivated in organic production systems]. Journal of Research and Applications in Agricultural Engineering 53 (4): $74-77$. 